\title{
Vedanta Resources plc and Another $v$ Lungowe and Others
}

\author{
SAMANTHA HOPKINS \\ Queen's University Belfast
}

\begin{abstract}
A s globalisation has expanded in recent years, a number of novel issues have arisen on the international stage regarding the relations and interaction between legal regimes both from the perspective of states (in contexts such as human trafficking), and from that of multinational corporations. One such issue in this latter context concerns liability of parent companies for actions or omissions of their (overseas) subsidiaries or branches especially considering the lack of transparency surrounding such relationships, and the very public face presented by a multinational. Given the potential for a claim to be brought in either of the two jurisdictions concerned, a number of cases have sought to bring some clarity to this decision.

Vedanta Resources plc and Another v Lungowe and Others ${ }^{1}$ is the latest in a line of cases in the UK courts concerning liability of parent companies for actions of foreign-domiciled subsidiaries. $A A A v$ Unilever plc ${ }^{2}$ and Okpabi and Others v Royal Dutch Shell plc and Another ${ }^{3}$ discussed, and were dismissed largely because of, lack of 'sufficient proximity' between the parent company and subsidiary to prompt a duty of care. As discussed below, this was one question of law on which the claimants succeeded in Vedanta: a common law duty of care was found. The implications of Vedanta for Okpabi upon its upcoming appeal (and similar future cases) in extending the applicability of a duty of care (in certain circumstances) to stakeholders other than employees or consumers are wide-ranging. Given the less than optimistic outcome for victims in both $A A A$ and (to date) Okpabi from a business and human rights perspective, it is hoped that Vedanta can contribute to a more victim-centred approach.
\end{abstract}

\section{Background and facts}

The case is a procedural one, in which Vedanta (the 'anchor defendant', based in the UK) and its self-regarded subsidiary company ${ }^{4}$ Konkola Copper Mines plc (KCM, the 'foreign defendant', based in Zambia) jointly raise a jurisdiction challenge to the claim of 1826 Zambian citizens against both companies. The material claim runs to the effect that KCM

\footnotetext{
[2019] UKSC 20.

[2018] EWCA Civ 1532.

[2018] EWCA Civ 191.

4 While the Zambian government has a significant minority stake in KCM, Vedanta has stated publicly that $\mathrm{KCM}$ is to be regarded as fully owned by Vedanta.
} 
has 'repeated[ly] discharge[d] . . toxic matter' 5 into local watercourses over 15 years, affecting both drinking water and irrigation, and consequently the health of the claimants - this is not at issue in the present case. Rather, the issue concerns whether the UK courts are the appropriate jurisdiction in which to determine whether Vedanta can be considered liable for the actions of KCM.

In bringing the case against both companies in the UK courts, the claimants have the continued possibility of succeeding against the parent, should the subsidiary become insolvent (or, as has occurred in this instance, come under state control prior to proposed liquidation). ${ }^{6}$ Against Vedanta, Article 4.1 of the Recast Brussels Regulation is relied upon by the claimants: 'persons domiciled in a member state shall . . . be sued in the courts of that member state" - thus allowing for potential recourse to UK rather than Zambian courts. Against KCM the claimants rely upon the 'necessary or proper party gateway'8 by which proceedings may be served outside of the jurisdiction concerned ${ }^{9}$ (para 3.1, Civil Procedure Rules Practice Direction 6B). The jurisdiction challenge was heard first in the High Court ${ }^{10}$ and dismissed, largely due to lack of access to justice on the part of the claimants, ${ }^{11}$ before being appealed to the Court of Appeal in 2017 and dismissed for much the same reasons. ${ }^{12}$

Four main issues of law were raised by the appellants at the Supreme Court and discussed in the judgment: 'abuse of EU law', 'real issue as against Vedanta', 'proper place' and 'substantial justice'. The court was unanimous in its findings on all four points, finding in the first and second no error of law on the part of the High Court judge, resolving the third in favour of the appellants, and the fourth against the appellants. The overall decision found that, as the UK courts were considered not to be the 'proper place' for the claim, the appeal might have been allowed, save for the issue of substantial justice, which saw the appeal dismissed and the jurisdictional choice of the UK upheld.

\section{Issues of law}

Prior to substantive examination of the legal issues, the court clarified that, as a matter of proportionality, it was considered prudent not to conduct a 'mini-trial' on such questions as jurisdiction challenges, ${ }^{13}$ meaning that the over 8000 documents submitted by the appellants were regarded as excessive. This is due to the primary role of the Supreme Court being to arbitrate matters of law, rather than those of fact. ${ }^{14}$

The first issue, alleged 'abuse of EU law' in the claimants' reliance on Article 4 of the Recast Brussels Regulation, will be omitted for the present circumstances, since no new reading of law was raised: the Supreme Court upheld three instances of precedent (both at national and EU level) in rejecting this claim, as well as the decision of the judge.

5 Vedanta (n 1) para 1.

6 Chris Mfula and Barbara Lewis, 'Explainer: Zambia's Moves on Vedanta, KCM Alarm Mining Industry' (Reuters, 31 May 2019) <https://uk.reuters.com/article/us-zambia-mining-vedanta-kcm-explainer/explainerzambias-moves-on-vedanta-kcm-alarm-mining-industry-idUKKCN1T11JT/>.

7 Regulation (EU) 1215/2012 on Jurisdiction and the Recognition and Enforcement of Judgments in Civil and Commercial Matters.

8 Ibid para 4.

9 That is, outside of Zambia.

10 [2016] EWHC 975 (TCC).

11 Which was again raised at the Supreme Court and is thus discussed below.

12 [2018] 1 WLR 3575.

13 Three Rivers District Council v Governor and Company of the Bank of England (No 3) [2003] 2 AC 1, para 95.

14 Vedanta (n 1) para 12. 
The second issue concerned the appellants' assertion that no real triable issue against Vedanta exists, based on 'the claimants' pleaded case and supporting evidence'15 - only against $\mathrm{KCM}$ as the perpetrators of the acts. Here the issue of law concerned whether Vedanta owes, due to its involvement in the workings of its subsidiary KCM, either a common law duty of care or statutory liability under Zambian legislation. The appellants claimed that such a finding 'would involve a novel and controversial extension of the boundaries of the tort of negligence'. ${ }^{16}$

While it is true that there is no immediate duty of care owed by a parent company to stakeholders of a subsidiary ${ }^{17}$ - and moreover that 'there is nothing special or conclusive about the bare parent/subsidiary relationship' 18 - there are certain instances when such a duty may be owed (as in both Chandler and the present case). Indeed, 'a parent company will only be found to be subject to a duty of care in relation to an activity of its subsidiary if ordinary, general principles of the law of tort regarding the imposition of a duty of care on the part of the parent ... are satisfied in the particular case' (emphasis added). ${ }^{19}$ This was affirmed by the Supreme Court, which found that no 'novel extension' of the tort was required, and thus that no more rigour was required in its identification than was in fact utilised by the judge. ${ }^{20}$ The issue of statutory liability was considered irrelevant, given the existence of a non-novel category of common law duty of care. ${ }^{21}$

The third issue dealt with the question of whether UK courts are 'the proper place in which to bring the claim'; 22 the appellants submitting that the phrase 'the claim' (as against KCM) differed from 'the case as a whole' - i.e. that the former ought to be read narrowly. ${ }^{23}$ This was the only finding on which the Supreme Court differed substantially (though notably while still disagreeing with the appellants' narrow reading of the CPR) from the previous rulings, which had both found in favour of the claimants on this point.

As a matter of fact it would appear, and indeed the Supreme Court found, that a claim by Zambian claimants concerning acts and effects in Zambia by a Zambian company, with a majority of Zambian witnesses, ought to be heard in Zambia rather than in England. While the judge also found this at a preliminary stage, the avoidance of an irreconcilable judgment (i.e. due to KCM potentially being sued in Zambia and Vedanta in England) was decisive in his ruling that England was the 'proper place' - as it was in OJSC VTB Bank v Parline Ltd, ${ }^{24}$ which was cited as precedent.

Here the Supreme Court found justifiable issue, as the avoidance of duplicated or irreconcilable judgments is not a requirement of Article 4's stipulation that an EU domiciliary ought to be sued in its state of domicile. Indeed, it is merely one factor which a claimant must consider when making a choice concerning jurisdiction: weighing the risk of irreconcilable judgments against the desire to bring proceedings in a single state (thereby avoiding that risk). In essence, the Supreme Court found that the irreconcilable judgments' doctrine has been overstated in its importance, both in OJSC VTB Bank and

15 Ibid para 17.

16 Ibid para 46.

17 Chandler v Cape plc [2012] 1 WLR 3111.

18 Vedanta (n 1) para 54.

$19 A A A$ (n 2) para 36.

20 Vedanta (n 1) para 60.

21 Ibid para 65.

22 CPR 6.37(3) para 66.

23 Vedanta (n 1) para 73.

24 [2013] EWHC 3538 (Comm). 
consequently by the judge, ${ }^{25}$ prompting a fresh examination of the factors concerned and the resultant finding that the 'proper place' was in fact Zambia and not England.

The fourth and final issue concerned the attainment of substantial justice, the appellants arguing that the judge's definition of 'substantial' had been too narrow. The judge found that both the absence of 'sufficiently substantial and suitably experienced legal teams to enable litigation of this size and complexity' and issues surrounding legal funding in Zambian courts would, from a factual perspective, preclude the claimants' access to substantial justice were the case heard in the foreign jurisdiction. ${ }^{26}$ This complies with the rule that in 'exceptional cases', 'non-availability of substantial justice' may be found where financial issues exist in a foreign jurisdiction. ${ }^{27}$ In supporting this decision, two similar Zambian cases were cited, both of which failed to achieve justice for the majority of claimants due to monetary issues. ${ }^{28}$

\section{Conclusions}

There are two main points which might be taken from this judgment, which has considerable impact on the way in which multinational corporations are perceived as legal entities. The first is the finding that a parent company can possess, in correct circumstances, a common law duty of care towards stakeholders of a subsidiary - the first such in any superior court globally. ${ }^{29}$ This thus goes some way towards fulfilling the UK's obligations as a state party to the International Covenant on Economic, Social and Cultural Rights (ICESCR), 30 in which states parties are 'require[d] . . to establish . . . parent company or group liability regimes'. ${ }^{31}$ The existence of such a duty of care (that is, an ordinary and not a novel one requiring an extension of the stages set out in Caparo Industries plc $v$ Dickman $)^{32}$ establishes a straightforward reading of liability where the parent company has itself accepted that liability in writing.

This leads to the second point, namely the significant weight afforded by the court to Vedanta's written documents in determining that duty of care towards stakeholders. This provides conclusive evidence in the decades-long debate in the business and human rights field regarding the purpose of corporate social reporting. ${ }^{33}$ In light of this judgment, it would seem that, at least to some degree, this purpose is to clarify responsibility for corporate actions. It necessarily follows that such reporting cannot

25 Vedanta (n 1) para 77.

26 Ibid para 89.

27 Ibid para 93.

28 Nyasulu v Konkola Copper Mines plc [2015] ZMSC 33; Shamilimo v Nitrogen Chemicals of Zambia Ltd (2007/HP/0725).

29 Robert McCorquodale, 'Parent Companies Can Have a Duty of Care for Environmental and Human Rights' (Cambridge Core Blog, 11 April 2019) <http://coreblog.cambridge.org/2019/04/11/parent-companies-canhave-a-duty-of-care-for-environmental-and-human-rights-impacts-vedanta-v-lungowe $/>$.

30 Ibid.

31 UN Committee on Economic, Social and Cultural Rights, 'General Comment 24 on State obligations under the ICESCR in the context of business activities' (2017) UN Doc E/C12/GC/24, para 44.

32 [1990] 2 AC 605.

33 Massimo Contrafatto, 'The Institutionalization of Social and Environmental Reporting' (2014) 39(6) Accounting, Organizations and Society 414, 415; Shuili Du and Edward Vieira, 'Striving for Legitimacy through Corporate Social Responsibility' (2012) 110(4) Journal of Business Ethics 413, 414; Reggy Hooghiemstra, 'Corporate Communication and Impression Management' (2000) 27 Journal of Business Ethics 54, 55. 
solely serve the function of 'window-dressing'34 if it may be relied upon in court due to the actions of a subsidiary.

This may further have the effect of prompting companies, especially multinationals and those with necessarily close relations to subsidiaries, to exercise more care in their audits of subsidiary companies in order to avoid potential liability for subsidiaries' negligence. Equally, however, the possibility exists that this decision might prompt a withdrawal of responsibility by parent companies; Vedanta did not possess a 100 per cent holding in KCM, but rather held itself out as being, for all intents and purposes, the parent company of the latter. It would be a simple matter indeed for a company to make no strong reference to a subsidiary one way or another.

Despite the admitted importance of these two points, it is worthwhile noting that the overall judgment severely limits the likelihood that a similar case will in future be decided in a similar manner: as was noted in the judgment, Zambia is one of the poorest countries in the world, and so long as there remains no means of quantifying 'nonattainment of substantial justice for reasons of funding', Vedanta may be very readily distinguished. It is thus likely that the 'substantial justice' issue will have to be more comprehensively addressed in future cases (such as the anticipated appeal of Okpabi), in order to avoid summary judgments concerning jurisdiction reaching the Supreme Court as a matter of course.

34 David Crowther, 'Corporate Social Reporting: Genuine Action or Window-Dressing?' in David Crowther and Lez Rayman-Bacchus (eds), Perspectives on Corporate Social Responsibility (Ashgate 2004). 
